\title{
ICT and farmers: lessons learned and future developments
}

\author{
Alexander B. Sideridis, Maria Koukouli and Eleni Antonopoulou ${ }^{1}$
}

\section{N F O}

Received 19 Oct. 2010

Accepted 24 Nov. 2010

Available on-line 30 Nov. 2010

Responsible Editor: K. Rajkai

Keywords:

ICT in Agriculture, digital

divide, agro education, farming

\begin{abstract}
$\underline{\text { A B S T R A C T }}$
Information and Communication Technologies (ICT) evolution is well advancing Moore's Law prediction of geometric progression of computer performance indexes. Indeed, these technologies are not only fast developed but, in addition, are giving birth to newer ones nicely branching existing "old fashion" ICT systems and tools. These innovations of ICT are not only regenerating traditional sciences, like Agriculture, and practices, like farming, but also, awake well neglected human sensitiveness and indifference for poverty, environmental protection, climatic deterioration issues and the future of our planet as a whole. To refer to a few examples of these innovations affecting Agriculture and Environmental Sciences: Cloud Computing provides equality in resources management and exploitability to small budget farms against the big ones. Web2 browser allows, as a platform, effective runtime environment and considerably easy access to applications by farmers lacking proper education and training. Parallel Computing brings exponentially increased core processing to low-end computers facilitating the use of huge computer power by small agricultural research units. Never the less agricultural and farming communities, in their majority, do not adopt new ICT tools and systems to the degree required for substantial agricultural development. In this paper, experience gained over the years is used to evaluate and reason poor performance in the area of applicability of ICT innovations and tools by the vast majority of farmers throughout the world.
\end{abstract}

\section{Introduction}

For the last thirty years there is a lot of discussion about the important role that Information and Communication Technologies (ICT) could play for a more effective application of new policies and practices in Agriculture and related activities. The emphatic application of ICT innovations in all those areas is one of various and persistent efforts to positively react to an accumulation of problems to politically neglected areas of farming, environmental degradation, resources deterioration and elimination worldwide. Indeed, a considerable amount of money has been spent by international and national organizations funding projects aiming not only to use but also to develop tailor-made ICT software and hardware systems and tools in support of the above practices. At the same time, scientists of the field throughout the world believed that ICT systems may comfort life in rural and remote areas, increase agricultural production, improve farmer's income and contribute much to their quality of life and willingness to live in rural areas.

Information technologies have penetrated and highly affected the development of science even if in theoretical and philosophical areas of human pursuit. Their attribute is catholically recognized even by their opponents. No one could possibly argue on the subject of the progress made by medical science and its successes in diagnosis and cure of incurable considered being diseases due to the application of ICT. Philosophical ideas, cultural achievements, poetry and literature, arts are now shared by anybody via internet and its web services. On the contrary, farming communities are persistent in refusing the full exploitation of ICT systems in their day-to-day practices. Internet and web services are not used by the

\footnotetext{
${ }^{1}$ Informatics Laboratory, Agricultural University of Athens, 75 lera Odos str., Athens 118 55, Greece as/mkou/eleni@aua.gr
} 
majority of farmers of a substantial number of countries in spite the availability of the appropriate infrastructure in rural areas. Is it a problem of digital divide and, if it is so, how could one explain their kin in using -in those countries lacking behind computer technology- sophisticate mobile technology and very recent technological innovations like the voltaic technology? Why ICT are not fully used for environmental protection, while agriculture - one of the main contributors in contamination of rural areasis not seriously considered and monitored by ICT in order to avoid unacceptable human activities and practices? Why still the young generation refuse to willingly follow farming activities of their parents and are moving, even if these days, to non-rural areas neglecting environmental disadvantages, career projects and quality of life as a whole? Could proper syllabus of the educational system of all grades (from the primary level to the university level) contribute to the elimination of the problems?

ICT evolution is well advancing Moore's Law prediction of geometric progression of computer performance indexes. Indeed, these technologies are not only fast developed but, in addition, are giving birth to newer ones nicely branching existing "old fashion" ICT systems and tools. These innovations of ICT are not only regenerating traditional sciences, like Agriculture, and practices, like farming, but also, awake well neglected human sensitiveness and indifference for poverty, environmental protection, expected dramatic climatic changes and the future of our planet as a whole. To refer to a few examples of these innovations affecting Agriculture and Environmental Sciences: Cloud Computing (Liang-Jie Zhang, 2009) provides equality in resources management and exploitability to small budget farms against the big ones. Web2 browser allows, as a platform, effective runtime environment and considerably easy access to applications by untrained satisfactorily farmers. Parallel Computing (Campbell, et al., 2010) brings exponentially increased core processing to low-end computers facilitating the use of huge computer power by small agricultural research units.

Certainly education, training and e-services play a very important role for ICT adoption by Agriculture and related areas of science (Sideridis, 2002, 2006b, 2009). Easy access to information, knowledge and eservices is a key factor. Availability of agricultural information, knowledge and services: plenty. Never the less, digital divide is still affecting a considerable portion of agricultural communities and farmers are digitally marginalised. Therefore, it is important to examine existing, design and develop new farm oriented tools based on the recent advances of ICT so that this knowledge and services will be easily accessed and fully exploited.

In this paper, experience gained in the field of ICT in Agriculture over the last thirty years is used to evaluate and reason poor performance in the area of applicability of ICT innovations and tools by the vast majority of farmers throughout the world. Since ICT adoption by farmers, through proper training and education, is a critical factor for renewal of agricultural and farming practices, historic data related to major advances in agriculture are given and confronted with those of ICT educational tools developed the last three decades in sections 2 and 3 respectively. Section 4 is focussing in training educational digital libraries, portals and repositories as the main ICT tools to today's avenues towards narrowing existing gap and digital divide barriers. Finally, in section 5 an attempt is made through the conclusions to provide answers to unanswered questions in relation to poor financial performance and growth of countries with an agricultural background and a profile of insignificant ICT support in agricultural practices. The reasons behind related problems -for such prestigious and socially well established in the past communities of farmers to decline- are analysed and an answer through, new means of education, is proposed.

\section{Major advances in Agriculture}

The last three decades of 19th century constitute a significant period for the agricultural field in Europe and the whole world (See Table 1). In the past, before this period, the population growth as well as the scarcity of the land has led to increased efforts in order to raise the production output per hectare. In the period 1870-1914, the process of the "modern economic growth" led to a strong land-saving direction, supported by the technological progress made in the field of agriculture. The innovative chemical 
fertilizers, the concentrated feeds as well as the use of new modern tools and machinery, and the cooperative movement strengthened the position of the farmers and contributed in the growth of the agricultural productivity (Zanden, 1991).

In the period 1914-1950, war technology was used in industry and agriculture, leading to the agricultural mechanization and the sufficiency of wheat while, on the other hand, the rise of the industrial era resulted in the reorientation of the workforce from farming to industry. These facts led to a gradual decline of the farmers' social status.

Finally, from 1950 until present, rising economies mainly based in industry were slowly diminishing the role of agriculture and farming in building financially strong economic communities. The emergence of new technologies and the focus on the industry, as well as the lack of proper education for the farmers in the new innovative tools and methods, caused the digital divide of people living in rural areas.

In the following table the status of the agriculture is pictured according to the period of time, from 1870 until present.

Table 1. Major "green” steps

\begin{tabular}{|c|c|}
\hline Era & Status \\
\hline $1870-1914$ & $\begin{array}{l}\text { 1st Green revolution in agriculture. } \\
\text { - } \\
\text { Innovations strengthened the position of small family farms (land-saving). } \\
\text { Growth of agricultural productivity (labour intensity). }\end{array}$ \\
\hline $1914-1950$ & $\begin{array}{l}\text { - } \\
\text { - } \\
\text { - } \\
\text { - } \\
\text { - }\end{array}$ \\
\hline 1950-present & $\begin{array}{l}\text { Digital era. } \\
\text { Digital divide. }\end{array}$ \\
\hline
\end{tabular}

\section{ICT fostering agriculture}

One sixth of the population of our planet, approximately one billion people, leaves in poverty and hunger, every six seconds one child on earth is dying (Diouf, 2010). These terrible statistics do not only show human indifference, insensibility and cruelty. They also magnify the important role of agricultural productivity. Increase of agricultural production could fight poverty. Therefore, any means towards this end should fully be exploited. Technology is the answer and ICT in particular could contribute much in achieving this goal. During the last twenty years policies have been adopted so that farmers should not be feeling neglected. Instead, they should be fully supported and change their profile. A business profile seemed to be the appropriate one. By this change, was expected to significantly improve farmer's income. They should not only produce, but they should also sell their production. The role of the intermediates should thus be reduced and farmers could make a better profit. Another approach and alternate policy in keeping agricultural production alive was to fully subsidise it.

Those farmers that supported their farming activities and their cultivars by making good use of available information, knowledge, existing information systems and tools had increased their productivity. If they were also capable of using e-services, e-commerce applications, existing portals etc., then they had benefited a lot as promoters and sellers of their agricultural products. Unfortunately, farmers of the above category represent a very low percentage, close to zero for countries left technologically behind. Simply, the large majority of farmers ignored ICT and could not efficiently increase their income. Those relying to subsidies are now -that subsidies period is close to end- collapsing down. As a more terrifying result of this disappointment of farming communities came urbanism. Farming land was devastated. 
During the same period of agricultural deterioration for farming communities refused to adopt advances in technology, information and communication sciences made spectacular progress in reaching human needs in all aspects of life. On the other hand, medical science made tremendous advances in diagnosis and cure as well as in reducing human diseases suffering. Medical and agricultural sciences' advances (human life and human nutrition safeguards respectively) show the importance and significance of ICT application and its benefit to humans respectively.

Apart from agriculture, closely related sciences like environmental and food sciences have not also been supported by ICT tools. Digital technologies and tools like RFID applications for example in animal husbandry and production are unknown territories, decision support systems, geographical information systems, remote sensing applications, web services e-government services, web and mobile computing applications for real time information, artificial intelligence applications, are fully ignored. Multimedia, portals and one shop stop centres for various operations in agriculture are known as academic exercises.

\section{ICT in Education: From past to present}

During the period of 1975 to 1985 , ICT emerges in the field of education in the form of local user interaction using behaviourist approaches for learning through instruction to programme in order to build tools and solve problems. During this period ICT is present in a Computer Assisted Learning form (CAL) (see Table 2).

The period of 1983 until 1990 the use of ICT in education evolves using the innovations of that time, introducing the Computer-Based training where the previous CAL models are combined with interactive multimedia courseware. The dominant model used during this period is the passive learner while constructivism influences the design and use of the educational software of that time.

As the Web technologies emerge from early '90, a rapid development of web based training methods occurs in the field of education. New forms of education are introduced, such as the Internet-based content delivery which is used in e-learning courses. The learner now interacts through the ICT tools provided and therefore has an active role in the educational procedure. In particular, from 1995 until present, the web based training evolution includes the delivery of Internet-based flexible courseware, characterized by increased interactivity for the learner. More recently, during the last decade, more comprehensive interactive web platforms and multimedia applications have been developed and are freely available to the public. These systems use English as the dominant language and a great percentage of them are of global coverage. Nearly half of them offer search services on various thematic areas. Important Agricultural areas on crops and animal production and health are fully covered and are addressed to target groups including policy makers, consumers, farmers, extension officers, students and pupils. Selected and scientifically filtered reliable and upgraded knowledge and information is available through these systems covering any possible need of the above stakeholders.

Digital Libraries (reports, studies, papers and legislations), directories of links, agencies, monitoring organizations legislation, law and administrative documents are platforms and systems developed recently with a tendency to spread horizontally to new areas of scientific and industrial communities. Agricultural systems of this kind are now gradually appearing and include market reports, trends, product prices, online shops and market directories. 
Table 2. ICT tools in education (1975-present) The changing focus of educational technology over the past 30 years. (Charp, 1997; Herrington, et al., 2005; Pilla, et al., 2006; Leinonen, 2005; MorteraGutiérrez, 2006; Nicholson \& Mc Dougall, 2005; Thomson, 2005).

\begin{tabular}{|l|l|l|}
\hline Era & \multicolumn{1}{|c|}{ Focus } & \multicolumn{1}{|c|}{ Educational characteristics } \\
\hline $1975-1985$ & $\begin{array}{l}\text { Programming; } \\
\text { Drill and practice; } \\
\text { Computer-assisted learning -CAL. }\end{array}$ & $\begin{array}{l}\text { Behaviourist approaches to learning and instruction; } \\
\text { programming to build tools and solve problems; } \\
\text { local user-computer interaction. }\end{array}$ \\
\hline $1983-1990$ & $\begin{array}{l}\text { Computer-Based Training; } \\
\text { Multimedia; }\end{array}$ & $\begin{array}{l}\text { Use of older CAL models with interactive multimedia } \\
\text { courseware; } \\
\text { Passive learner models dominant; } \\
\text { Constructivist influences begin to appear in } \\
\text { educational software design and use. }\end{array}$ \\
\hline $1990-1995$ & Web-based Training & $\begin{array}{l}\text { Internet-based content delivery; } \\
\text { Active learner models developed; } \\
\text { Constructivist perspectives common; } \\
\text { Limited end-user interactions. }\end{array}$ \\
\hline 1995 -present & E-Learning and social networking & $\begin{array}{l}\text { Internet-based flexible courseware deliver; } \\
\text { increased interactivity; } \\
\text { online multimedia courseware; } \\
\text { Distributed constructivist and cognitive models } \\
\text { common; Remote user-user interactions. }\end{array}$ \\
\hline
\end{tabular}

\section{Conclusions}

In the last thirty years there has been amazing progress on ICT systems, tools and methodologies. Innovations in hardware and software have generalized the use of digital technologies and systems in every aspect of human intervention and activities. E- Government services have simplified complex transactions, automation makes arduous processes routine's work. Networking, Internet and web offer global infrastructure for any kind of worldwide communication and interaction (Sideridis \& Yialouris, 2002; Sideridis, 2008; Sideridis \& Pimenidis, 2009). Social networking brought humans closer to a better understanding and reduces distance barriers. All this technological revolution affecting so impressively human life is enjoyed by hardly half the population of our planet. For the other half, innovations of this kind remain a dream, an untouched reality primary due to lack of internet connectivity. This division of today's world is should not astonish us. Consider the high percentage $(20 \%)$ of world's population starving to death. In conclusion, we should never forget that one billion people have no enough food and it is obvious that developments in agriculture is the only way for solving the problem of people's starvation. 
Table 3. Networking applications development: The transition from the traditional communication approach to the new web communication tools that can be used in the field of agriculture.

\begin{tabular}{|c|l|l|}
\hline $\begin{array}{c}\text { Communication } \\
\text { approach }\end{array}$ & \multicolumn{1}{c|}{$\begin{array}{c}\text { Traditional } \\
\text { agricultural applications }\end{array}$} & Examples of web (Web 2.0) tools \\
\hline One-way communication & $\begin{array}{l}\text { Newsletter, } \\
\text { FarmNote, } \\
\text { book }\end{array}$ & $\begin{array}{l}\text { Web page, } \\
\text { Targeted email campaign, } \\
\text { SMS messaging, } \\
\text { RSS Feeds }\end{array}$ \\
\hline One-way text & $\begin{array}{l}\text { Movie/video, } \\
\text { field day, } \\
\text { seminar }\end{array}$ & $\begin{array}{l}\text { Podcast, } \\
\text { Webcast }\end{array}$ \\
\hline One-way audio-visual & \multicolumn{2}{|c|}{$\begin{array}{l}\text { Blogs, } \\
\text { eSurvey, } \\
\text { Wiki, } \\
\text { Chats (Twitter) }\end{array}$} \\
\hline Two-way text & $\begin{array}{l}\text { Letter, } \\
\text { survey }\end{array}$ & $\begin{array}{l}\text { Video Chats (Web-conference), } \\
\text { Social networking (Facebook), } \\
\text { Photo sharing }\end{array}$ \\
\hline Two-way audio-visual & Workshop, \\
\end{tabular}

In a considerable number of countries, technological innovations have not been adopted by farmers. Although Agriculture seem to be a first priority subject of political agendas and common policies and measures have been designed by international organizations, like the European Union and FAO, developments do not stop or, at least, reduce an agricultural deterioration. Digital divide remains still a problem for agriculture and farming communities in spite of being, quite often, the subject of lengthy debates of many world forums organised be the United Nations, IMF, the World Bank, OECD, FAO, Agricultural Universities and international and national agricultural associations.

Education and new forms of training for farmers will certainly eliminate the problem. Change of farmer's profile, through appropriately designed training courses, to a more businesslike, will certainly improve his income and keep his farm going. In this new role, farmers undoubtedly will -and have tomake full use of ICT's new advances. Therefore, further effort is needed (i) to sweep away scarce of expertise on ICT by farmers' advisors and (ii), through them, to sweep away scarce of farmers on ICT. Expected improved adaptive capability of farmers and new, recently designed ICT training tools, will then be used to bring farmers to the desired level of digital literacy. European projects' results applied to particular agricultural areas of interest in this field, like those of Bioagro (Sideridis, 2006a, 2006b) and Organic Edunet (Patrikakis, et al., 2008), will certainly contribute much to the above aim in life of ICT experts in Agriculture.

\section{References}

Campbell, C., Johnson, R., Miller, A., Toub, S. 2010. Parallel Parallel Programming with Microsoft .NET-Design Patterns for Decomposition and Coordination on Multicore Architectures. Microsoft patterns \& practices http://msdn.microsoft.com/en-us/concurrency/default.aspx

Charp, S. 1997. Some reflections. (the 30-year history of computers in education). T H E Journal (Technological Horizons In Education), 24(1), 8-11.

Diouf, J. 2010. Oral presentation of Dr. Jacques Diouf, General Director of FAO, on the occasion of being nominated honorary doctor of the Agricultural University of Athens,. Athens 6 October, 2010. 
Herrington, J., Reeves, T., R. Oliver. 2005. Online Learning as Information Delivery: Digital Myopia. Journal of Interactive Learning Research, 16(4), 353-367.

Leinonen, T. 2005. (Critical) history of ICT in education - and where we are heading? [Electronic Version]. FLOSSE Posse. Free, Libre and Open Source Software in Education, 23 June. Retrieved 31-08-2006 from underline http://flosse.dicole.org.

Liang-Jie Zhang, 2009. http://www.thecloudcomputing.org/2009/1/tutorials.html

Mortera-Gutièrrez, F.2006. Faculty Best Practices Using Blended Learning in E-Learning and Face-to-Face Instruction. International Journal on E-Learning, 5(3), 313-337.

Nicholson, P. S., \& McDougall, A. 2005. eLearning: 40 Years of Evolution? In IFIP (Ed.), The eighth IFIP World Conference on Computers in Education [ISI 1571-5736]. Stellenbosch, ZA: IFIP.

Patrikakis, Ch. Z., M. Koukouli, C. Costopoulou, and A.B. Sideridis. 2008, Content Requirements Identification towards the Design of an Educational Portal, First World Summit on the Knowledge Society, WSKS 2008, Athens, Greece. Pilla, B. S., Nakayama, M. K., et al. (in press). Characterising E-learning practices. In Proceedings of WCC2002, Santiago, Chile, July 2006 [ISSN: 1571-5736]. New York: Springer.

Pilla, B. S., Nakayama, M. K., Nicholson, P., 2006. Characterising E-learning practices. In. Proceedings of WCC2002, Santiago.

Sideridis, A. B., C. P. Yialouris. 2002. The impact of ICT in Agriculture, Food and Environment. Next Generation Society: Technological and Legal Issues, (A. B. Sideridis editor). Proceedings of the 1st International HAICTA Conference, Athens, Greece.

Sideridis, A. B. 2006a. Electronic Democracy: Challenges of the Digital Era, (A. B. Sideridis editor). Proceedings of the 2nd International HSCIS Conference, Athens, Greece.

Sideridis, A. B. 2006b. New ICT Concepts and Projects for the Development of Rural Areas: The project Bio@gro, International Conference "Sustainable Management and Development of Mountainous and Island Areas", Naxos, Greece.

Sideridis, A. B. 2008. Information \& Communication Technologies in Bio \& Earth Sciences, (A. B. Sideridis editor). Proceedings of the 4th International HAICTA Conference, Athens, Greece.

Sideridis, A. B.and E. Pimenidis. 2009. Mobile devises and services. International Journal of Electronic Security and Digital Forensics, 2(4): 335-444.

Sideridis, A. B. 2009. Next Generation Society: Technological and Legal Issues, (A. B. Sideridis editor). Proceedings of the Third International Conference, e-Democracy 2009, November 2009, Vol.2.

Thomson, J. 2005. History of E-Learning (http://www.knowledgenet.com/corporateinformation/ourhistory/history.jsp).

Zanden, J. L. 1991. The first green revolution: the growth of production and productivity in European agriculture, 1870-1914. Economic History Review. I99I, 44 (2), 215-239. 